\title{
Björn Heile, Charles Wilson (eds.), The Routledge Research Companion to Modernism in Music
}

Abingdon, Routledge, 2019

\section{Max Erwin}

\section{(2) OpenEdition}

\section{Journals}

Electronic version

URL: http://journals.openedition.org/transposition/5602

DOI: $10.4000 /$ transposition.5602

ISSN: 2110-6134

Publisher

CRAL - Centre de recherche sur les arts et le langage

Electronic reference

Max Erwin, "Björn Heile, Charles Wilson (eds.), The Routledge Research Companion to Modernism in Music", Transposition [Online], 9 | 2021, Online since 15 December 2020, connection on 23 April 2021 URL: http://journals.openedition.org/transposition/5602 ; DOI: https://doi.org/10.4000/transposition. 5602

This text was automatically generated on 23 April 2021.

\section{(c) (1) (-)}

La revue Transposition est mise à disposition selon les termes de la Licence Creative Commons Attribution - Partage dans les Mêmes Conditions 4.0 International. 


\title{
Björn Heile, Charles Wilson (eds.), The Routledge Research Companion to Modernism in Music
}

Abingdon, Routledge, 2019

\author{
Max Erwin
}

\section{REFERENCES}

Björn Heile, Charles Wilson (eds.), The Routledge Research Companion to Modernism in Music, Abingdon, Routledge, 2019, 518 p.

1 This is a very large book. It is over 500 pages of 1.5 spaced A4 paper in very small (11point, I believe) font. Its editors, Björn Heile and Charles Wilson, have assembled a dense phalanx of scholars offering interpretations and methodological approaches to the question of musical modernism which often diverge and mutually contradict. Some, like J. P. E. Harper-Scott, present what is in essence a primer to a much more detailed and expansive methodological framework. Others, like Mark Berry and Eva Moreda Rodríguez, provide what read like corollaries to a broader research project that they have been working on for some time, as sort of cross-sections of contemporary scholarship on expanded musical modernisms. Still others take a far more metaapproach, as in Martin Iddon's chapter, which gives something of a précis of how various methodologies institutional studies might be fruitfully applied to various centres of New Music.

In view of the book's sheer bulk, it is not exactly clear what a short review could hope to achieve and how it would hope to go about achieving it. The temptation to give a blow-by-blow account quickly runs into a map-vs-territory problem where the review spirals into helplessly meagre summaries of the individual chapters. There also might be the expectation that a scholarly assessment such as this would address the question of whether or not the object under review was, on the level, worth purchasing. To 
address that issue immediately, if you have encountered this review from an interest in whether or not this book would be helpful to your scholarly or devoted amateur interest in musical modernism, it certainly is. If you have $£ 150$ lying around, you might well choose to purchase it; if not, it is an eminently worthy and even essential addition to recommend to your university's library.

With that out of the way, I think the most fruitful way of approaching this book is reckoning with it on its own terms, or rather, the terms set out by its editors in their introduction (itself hefty, ambitious, and voluminous). This reads like something of a victory lap: Modernism is back, baby, and it's better than ever. Heile and Wilson begin by noting how 'the pendulum has swung in the other direction' since the 1990s, wresting scholarly attention from the clutches of postmodernism (and, to a lesser extent, new musicology?) back to the incomplete project of modernity (p. 1). They go so far as to term this, perhaps a bit tongue in cheek, the 'eclipse of [modernism's] erstwhile adversary' (ibid). Eclipse does seem to be the right word, though, and, as Heile and Wilson suggest, it is indeed striking: the critiques of modernism by the 1980s (or thereabouts) generation have led (in the editors' telling) not to a wholesale repudiation of the modernist project but an expanded understanding of what modernism does in the world and where and how it does it. If a unified orientation might be identified from the 20 scholars represented here, it would be this sustained enlargement of the remit of modernism.

While Heile and Wilson's account of modernism's resurrection does occasionally veer into the sort of shopworn Adornoisms for which critics of modernism are doubtlessly well prepared (the 'hegemonic' production of popular music is juxtaposed with the 'powerful instances of resistance' allotted to more autonomous practices), this is not to say that they are blinkered by triumphalism. Quite the contrary - the bulk of their introduction is a measured meditation on how one, at this late juncture, could possibly frame 'modernism' in a manner that is neither crassly reductionist nor hopelessly nebulous. To this end, they clarify that the subject that this book treats is not 'musical modernism' but 'modernism in music' (pp. 3-4). This distinction appears rather oblique to my mind, and may well just be Heile and Wilson's earnest attempt to thread the needle of providing some sort of coherent definition of what 'musical modernism' should look like (and they are commendably forthright in their trepidation concerning this expectation). Oblique as it may be, such a transmedial understanding of modernism permeates the book's ethos - it is doubtless why the cover features an image from Walter Ruttmann's 1927 film Berlin: Sinfonie der Großstadt rather than, say, a sketch of pitch multiplication from Le Marteau sans maitre.

5 Such an expanded concern with modernism in the arts is reflected in the two leitfiguren of Virginia Woolf and José Ortega y Gasset, which raise the issues of periodisation and dehumanisation, respectively, in aesthetic modernity. Ortega y Gasset, one of Richard Taruskin's favourite bad-modernist whipping boys, is here shown to have 'impeccably democratic' political convictions (p.11), his theorising of 'depersonalisation' amounting to little more than a level-headed aesthetic preference for the same classicism that Taruskin finds so epochal in Stravinsky (ibid). Taruskin's notoriously fast-and-loose historicism aside, Heile and Wilson seem to be at pains here to argue for something of a kinder, gentler modernism. To this end, Ben Earle's concerns that 'modernism is essentially anti-liberal' are acknowledged but put to one side as unhelpfully reductive - useful conclusions for Earle's Italian subjects which need not be 
expanded to the totality of the expanded definition of modernism Heile and Wilson operate with. The real dehumanising impulse, Heile and Wilson seem to suggest in a particularly insightful section of their argument, is that of the historian who, blighted by kulturpessimismus, reads modernism as the last, desperate stand of aesthetic literacy (the examples they give are Taruskin, Julian Johnson, and Arnold Whittall's own contribution to the volume).

6 If the issue of objectification is effectively put to one side - a phenomenon for the latter-day historians and critics rather than those in situ - periodisation, conversely, is an issue at the core of what is at stake for Heile and Wilson's framing of modernism in music. To this end, Woolf's oft-repeated formulation of some irreparable transformation - glossed by Heile and Wilson as an 'epistemic break' - occurring 'on or about December 1910' is used to elevate the issue of periodisation from a question of definable 'watershed' moments to one of 'an epistemic consciousness [...] an "epistemological horizon" which then becomes available over a longer period' (pp. 3-4). This sounds more than a little like a certain bird of Hegel's that takes flight at dusk, and Foucault himself was rather cagey about the parallels between his methods and a straightforward 'history of ideas' approach (see the Q\&A section of The Archaeology of Knowledge). ${ }^{1}$ In any case, what interests Heile and Wilson is both the positioning of this break and its musical enunciations. While Heile and Wilson don't themselves give a straight answer for when precisely they believe the episteme of modernism to have been let loose, they do note that individual contributions to the Companion both scrutinise previous answers - e.g. David Code's reading of Boulez positioning the birth of musical modernism securely in the Parisian metropole with Debussy's Prélude à l'après-midi d'un faune (1894) - and provide their own - Whittall proposing late Beethoven and James Currie proposing Offenbach's Orphée aux enfers (1858).

7 What concerns Heile and Wilson the most is the precise nature of this episteme of modernism, and how it might be effectively defined and written about by scholars. To this end, they use the analogy (or at least I think it's an analogy) of 'a series of family resemblances, whereby different members of the family may share certain features but none is common to all of them, and where distant members may be connected by a chain of resemblances without sharing a single feature in common.' (p. 12) Such an analogic taxonomy presupposes a remarkably stable modernist Imaginary, work on which is done with in the Companion by Harper-Scott and without it in Seth Brodsky's From 1989, or European Music and the Modernist Unconscious. ${ }^{2}$

8 As I say, the book is far too expansive to be adequately grappled with on a chapter-bychapter basis, but I would like to give some quick highlights from the various contributors, if only to give my editors the impression that I have indeed read the thing. Exemplary among the chapters is Sarah Collins writing on the C in the ISCM (International Society for Contemporary Music) and Robert Adlington on applications of modernism towards notions of egalitarian social design, and Harper-Scott's chapter provides a characteristically full-throated and eminently readable conceptual framework that is remarkably wide-ranging. Ian Pace's synoptic review of the book in JRMA also gives a thoughtful account of the contributions and itself identifies points of scholarly departure not taken up by the Companion (to my mind, his most penetrating insight is the ideological importance of Hans Pfitzner's writings, which seem to fit the bill of a 'constitutive outside' for modernism proposed by Heile and Wilson). ${ }^{3}$ Pace's intervention is also useful in further emphasising the fractures of musical modernism 
studies: he committedly goes to bat for Harper-Scott's conceptual framework while tarring more sociologically-minded approaches as 'crypto-capitalist' (a term borrowed from Harper-Scott which, the reader assumes, indicates something very nearly as bad as capitalism). This seems broadly representative of a particular established line of criticism against postmodernism, in which critiques against the perceived elitism of modernism (themselves given sustained treatment in Moreda Rodríguez's chapter) are read as a wholesale advocacy of neoliberal reforms to cultural institutions.

Such a counter-argument risks overlooking just how similar these respective positions actually are. Taken as a whole, what is most striking about this Companion is that the new frontiers of modernism in music seem to be precisely those that 'postmodernist' critics, practitioners, and scholars had been mapping for their own project. Wilson reverses this observation in his chapter, stating that perspectives that appear to question modernist ideals and practices' quite often 'turn out to be dependent on them after all' (pp. 258-286). As framed by the Companion, this is less of a realignment of modernism than a recuperation of an emancipatory intellectual project that has been previously allotted insufficient attention within modernism. The result, then, is not a postmodernism of the centre but a modernism (a re-modernism?) of the peripheries music of exile, music of margins, music of resistance. Indeed, Heile and Wilson playfully refer to Moreda Rodríguez's chapter as making a pitch for "“The New Modernism Studies" "m', a field 'free from all associations with elitism, sexism, classism and racism' (p. 15); the chapter itself is implicitly premised on the idea that the modernists were the ones who fled fascism. For his part, Adlington goes some ways further in teasing out the complexities of a modernism (or an avant-garde, Adlington seems more game to incorporate Bürger's theorising than his editors) which at once appears to herald both a radical democratisation of art and the monumental spectacle of fascism. The question which remains, with both erstwhile-postmodernism and enduring-new-modernism, is what's left to be hegemonic? The answer, repeatedly, is neoliberalism. Perhaps this might be the most fruitful point of departure for The New Modernism Studies addressing neoliberalism not only as a hegemony to be resisted but as a conceptual regime imbricated with artistic production and critique.

\section{NOTES}

1. FOUCAult Michel, The Archaeology of Knowledge, Oxon, Routledge, 2002, pp. 219-231.

2. BRODSKY Seth, From 1989, or European Music and the Modernist Unconscious, Berkeley, University of California Press, 2017.

3. PACE Ian, 'Modernist Fantasias: The Recuperation of a Concept', Journal of the Royal Musical Association, vol. 144, no. 2, 2019, pp. 473-493. 


\section{AUTHORS}

\section{MAX ERWIN}

Max Erwin is a musicologist and composer. His research is primarily focused on musical avantgardes and their institutional networks. He completed his PhD at the University of Leeds in 2020 and is currently Lecturer at the University of Malta. His writing appears in Tempo, TwentiethCentury Music, Perspectives of New Music, Music \& Literature, Revue belge de Musicologie, Nuove Musiche, and Cacophony. 